\title{
Language Impediment and Polyglot Actors in Yoruba Native Film
}

\author{
Adejoke Adetoun Ademuyiwa ${ }^{*}$, Eunice Uwadinma-Idemudia \\ Department of Theatre Arts, Redeemer's University, Nigeria
}

Received December 4, 2020; Revised January 21, 2021; Accepted March 12, 2021

\section{Cite This Paper in the following Citation Styles}

(a): [1] Adejoke Adetoun Ademuyiwa, Eunice Uwadinma-Idemudia, "Language Impediment and Polyglot Actors in Yoruba Native Film," Linguistics and Literature Studies, Vol. 9, No. 3, pp. 73 - 83, 2021. DOI: 10.13189/lls.2021.090301.

(b): Adejoke Adetoun Ademuyiwa, Eunice Uwadinma-Idemudia (2021). Language Impediment and Polyglot Actors in Yoruba Native Film. Linguistics and Literature Studies, 9(3), 73 - 83. DOI: 10.13189/lls.2021.090301.

Copyright $\odot 2021$ by authors, all rights reserved. Authors agree that this article remains permanently open access under the terms of the Creative Commons Attribution License 4.0 International License

\begin{abstract}
In the Yoruba Nollywood film industry, there is a crop of non-native actors who are fluent in their native language and also conversant in the Yoruba language. These actors fail to articulate the level of believability in indigenised Yoruba cultural films, due to the linguistic impediment of their native language in the required diction of cultural films. This paper refers to them as polyglots and discusses their inability to acculturate linguistically in culture-based films through characterisation, diction, gesticulations and socio-cultural nuances. This paper, therefore, explores the inadequacy of language delivery due to linguistic impediment of the native language of select polyglot actors in Yoruba Nollywood films as a hindrance to adequate interpretation of Yoruba language. Three non- native actors in native Yoruba films were studied, and their linguistic performances were content analysed in line with the impediment of their mother tongue. The paper adopts the Social Learning Theory of Albert Bandura, which identifies the impact of language on the audience, and sees the actor as a part of models to either elevate or denigrate ethical values of language in society. The research is premised on Qualitative method of research in analysing the visual film materials to identify linguistic strength and deficiency of the Yoruba language in performance. Findings show that actors who underplay nativity through language undervalue linguistic appreciation of the audience, and also reduce the cultural values the films are meant to propagate.
\end{abstract}

Keywords Language, Impediment, Polyglots, Nollywood, Linguistic, Actors

\section{Introduction}

Nollywood is the Nigerian film industry, following the American film culture, Hollywood, as well as Bollywood in India. Like its counterparts in the developed world, the Nigerian Nollywood industry depicts the socio-cultural milieu of Nigeria, with her multiple and identifiable ethnic configurations. [1] This industry, as "the video film industry of the Nigerian people" and "the Nigerian National cinema". In delineating the Nollywood film, [2] identifies it as "the contemporary Nigerian Film Industry." This categorisation suggests a newness of Nollywood industry that has evolved through its history with the vigour of modernity and relevance. Nigeria consists of many ethnic identities, identified by language, cultural diversity and other concrete and non-concrete values. [3] Comments "The multilingual character of Nigeria is reflected in all aspects of the national life, including filmmaking". He suggests further that in the Nigeria industry; there is no isolation of perspectives, but a conglomerate, "woods". The Yoruba version of Nollywood, for instance, refers to films in the Yoruba language, in some quarters; it is known as Nollywood Yoruba. In the northern part of the country, another variant of the 'wood' is known as Kannywood, referring to films in the Hausa language spoken majority of the Northern population of Nigeria. The last popular variant is naturally that of the Ibo speaking people of the western part of the country referred to as 'Ibo films'. In all of these 'woods', language is the key distinguishing factor of their identity. 
In Nollywood Yoruba, there is a crop of non-native Yoruba actors who have gained their popularity by participating in Yoruba films, these actors with time have also improved in skills and creativity in their participation in Yoruba epic or cultured films. These crops of actors include Toyin Aimakhu, Fathia Balogun, Ricardo Agbor, Mercy Aigbe, Kelvin Ikeduba, Ibrahim Chattah and a host of others. Ricardo Agbor, Toyin Aimakhu and Fathia Balogun are case studies whose performances are analysed against the backdrop of language impediment in selected works. These works include Asa, by Fathia Balogun, Kolokolo by Yinka Laoye, and Ifa Iwa, by Abdu Lateef Titilope.

Language forms the fundamental element for cultural identity and a useful tool for communication in drama and performance. It transforms the written text into actual performance. In the cultural milieu, language is a function or verbal behaviour that occurs amongst individuals in the same space. A child's first language is referred to as the mother tongue, while others are regarded as the second or third language as the case may be. Most times, the first language gives the identity of ethnicity; the deficiency of the first language in the rendition of a second language is dependent on the linguistic dexterity of the speaker. In performance, the actor presents an identity for the character he is playing, by situating the story in a believable locale, therefore, the language of communication he deploys becomes the language of the character, unless the lines are delivered in the second language or the lingua franca that emerges most times as the second language. Language impediment is the linguistic influence of a mother tongue in the expected language of delivery by the non- native actor in a native play performance. Actors who fall into this category are the non-native polyglot actors who can also be referred to as multilingual actors. In Nollywood Yoruba films, they are cast to feature, not only as Yoruba characters but as characters with Yoruba native dialect. Some epic films, parade polyglot actors with language impediment which resultantly causes disorientation in the aesthetic value of their performances as seen in the actor's mother tongue impediment.

However, because of its accessibility to a broader audience, the dramatic genre of films is easily an aesthetic and valuable tool of communication, primarily because of its audio-visual nature, for this reason, this study examines the linguistic ability of polyglot actors in selected cultural movies and how linguistic impediment affects the general output of performance and its impact on the audience.

\section{Language as Film Culture}

Film stories are localised in a setting, informed through language, which aids the viewers in the interpretation of the film story. Through language, meanings are derived in everyday interaction. [3] "speakers use language to convey their thoughts, feelings, intentions, and desires to others and to remain relevant in a cultural environment, we learn about people through what they say and how they say it, we learn about ourselves through the ways that other people react to what we say, and we learn about our relationships with the give and take of communicative interactions". Proper communication has an essential social function in fostering feelings of group identity and solidarity. Ishola [4] indicates that "God has demonstrated his preference for diversity, both in humankind, culture and his ecology. He has also created a unique language for each culture to ensure effective and independent operation". In film or play performance, language is synonymous with nativity; language impediment minimises characterisation as the actor could be stagnated in character flow while attempting to code-switch from one language to the other. The result of this linguistic conflict is a deficiency in characterisation and possible disorientation in the audience that can result from wrong message transferring from the actors to the audience. This makes language be a vital tool to drama and theatre, as it could be seen as a vehicle with which the message in performance is expressed.

The indigenous language films always demand that, actors not only speak the language of the setting but that they must also observe the social rules peculiar to the cultural milieu of the story. The social rules of performance rely solely on the condition of speech and its ethnic signification. Zentella describes her experience in a cross-lingual film she acted in as follows:

This made sense to me as it corroborated what I have learnt as the daughter of a Mexican father and a Puerto Rican mother, for example, that it was not only of the difference between 'frijoles' and 'habi-chuelas' in the lexicon or the presence or absence of syllable final-sin the phonology that I had to display in Mexican or Puerto Rican setting but ways of answering, greeting, leave-taking, praying and being. [5]

The above, summarily indicates that being able to act is not enough to delve into the language space of another culture without having a grounded cultural background into the core linguistic and intrinsic meaning of that language. The non-native polyglot actor must acculturate, not only in speech and dialect but also nuances identified with the locals who are the original speakers of the dialect.

\section{Polyglots}

Polyglot actors are multilingual/bilingual actors with the command of their ethnic language and having a conversational disposition towards their second or third language. [6] Definition of a bilingual is "one who switches from one language to the other according to the appropriate changes in the speech situations, but not in the 
unchanged speech situations".

The polyglot or bilingual actor in a native film setting must not only display knowledge of the correct language, but they also need, to be competent in the dialect as well as the social rules of that language. The multilingual actor can express the life of a character be it religious, cultural or philosophically articulated through language. Identity is expressed through language and that consciously or unconsciously, speakers use speech to signal their sense of themselves as belonging to group A and being different from group B.

\section{Language Impediment}

Just as communication is essential to language, impediment is also detrimental to language understanding. Merriam-Webster dictionary defines impediment as something that makes it difficult to do or complete something, or a condition that makes it difficult to speak normally. In native Yoruba films, polyglots who are cast, in films experience the influence of the mother tongue, which is non-Yoruba on the native Yoruba dialect they are expected to deliver. The mother tongue also referred to as the 'first language' of contact has an overbearing influence on the indigenous dialect and the implication of this influence has led to linguistic impediment for any other language spoken by the native speaker. Such influence, which includes elements of speech, such as, intonation, rhyme, speech and sounds, affect the target language, which in most cases is the second or third language. Language impediment corrupts the Yoruba native language through the mother tongue acquired.

\section{Albert Bandura's Social Learning Theory}

[7] A clinical psychologist who believes that learning is not limited to the classroom, but also by observing role models in everyday life, including characters in movies and television programme. The Social Learning Theory is a sociological theory that seeks to explain the cause of human behaviour. Bandura argues that the theory places emphasis on the critical role played by models. He reiterates further that human behaviour is patterned on the external forces, which serve as a stimulus, not by internal force or organism, but by the environment. In his argument, he states that the theory places particular emphasis on the essential roles played by vicarious, symbolic and self-regulatory processes, which receive relatively little attention even in most contemporary theories of learning.

As a theory of impact, Adeleke [8] posits in his discussion and findings on audience study that "a large percentage of the respondents submits that Yoruba films are capable of influencing the individual behaviour" mostly when the wrong meaning is communicated due to tonal inabilities of actors to communicate cultural meanings in a language, which is essential elements that make up a good society. Improper use of language, especially in the context of performance may lead to a gradual adulteration or damaged, and ultimately, an extinction of societal core values.

The impact of language use either in its proper or adulterated form on the audience necessitates the use of The Social Learning Theory (SLT) by Albert Bandura as a theoretical framework for this study. The Social Learning Theory is about the impact not just on style, but of the use of language as it affects the viewing audience. The theory recognises learning and behavioural change through the observation of concrete models in the guise of actors who are active role models in today's cultural evolution.

\section{Justification for Adopting the Social Learning Theory in the Study}

The impact of film on the audience necessitates the use of The Social Learning Theory (SLT) by Albert Bandura as a theoretical framework for this study. The Social Learning Theory is about impact as it affects the viewing audience; hence polyglot actors selected in the study to explore the impact of nativity within the framework of culture and language, and in characterization of indigenous films. The audience or the viewers are the content valuers and an important segment in the tripartite elements of drama, which are: the play, the stage (location) and the audience. Further, the general principles of SLT posit that learning takes place via observation, imitation and modelling. The theory recognizes learning, behavioural change through the observation of concrete models. Thus, the film audience is transported to the world of the story, affected by the situations, and psychologically or unconsciously develops an imitating mechanism of the role models. The level of the effectiveness is the level of impact. Impact is an experience, which can lead to learning by observation and emulation as postulated in SLT. [9] Also, Driscoll defines learning as a persisting change in human performance potential as a result of the learner's interaction with the environment.

This research recognizes such interaction in actors and spectators' relationship as a form of learning interactions. Weinstein and Meyer [10], also defines learning as the relatively permanent change in a person's knowledge of behaviour due to experience." For Shuell [11], learning is an enduring change in behaviour, or in the capacity to behave in a given fashion, which results from practice or other forms of experience. In all the definitions, learning is closely related to behaviour changes or a change in behaviour or behaviour in a specifically attributed fashion, which is culminated, from a form of experience.

Hence, the assumption that film audience has encounters with the characters in previewed films at the moment of performance is corroborated by Munroe and 
Jeffery [12], who observe that the theory encompasses attention, memory, and motivation which the video film supplies. For Bandura, learning is not complete with direct experience or reinforcement alone, for that reason, he added a social element, which this study interprets as film. It also argues that people learn new information and behaviour by watching other people. The people being observed are the Models. There are three basic models according to Bandura they are: one, a live model, two, a verbal instructional model; and three, a symbolic model.

While a live model demonstrates behaviour, the instructional model describes behaviour. The actor is the model personae that fit into the symbolic model. The actor acts out the behaviour as a fictional character. Actors in the video films are some of the social elements, which aid learning through the audio-visual appeal of its cinematic structure.

\section{Linguistic Competence and Characterisation Nexus}

One of the elements of believable acting is the right oral interpretation of the role. Between language and communication, the actor needs to communicate. Gumperz [13] opines that "whereas, linguistic competence covers the speakers ability to produce grammatically correct sentences." Also, that "communicative competence describes his ability to select from the totality of the grammatically correct expressions available to him," from "forms which appropriately reflect the social norms governing behaviour in specific encounters" The actor may produce the correct grammar in pronunciation, but fail to produce the right meaning. Example of words in Yoruba with the same spelling but different meaning includes,

$$
\begin{aligned}
& \text { 1. Oko (farm) } \\
& \text { Oko (pebble) } \\
& \text { 2. Ogun (inheritance) } \\
& \text { Ogun (twenty) } \\
& \text { 3. Ise (work) } \\
& \text { Ise (poverty) }
\end{aligned}
$$

The link between language and communication is the hurdle the polyglot actor needs to cross. The absence of Yoruba nativity in Yoruba native characterisation creates a defect in role interpretation. When the non-native polyglot mispronounces words with a different meaning from the original, then there will be a problem in role interpretation. Influence of mother tongue language creates a dysfunctional character; it also sends wrong information signals between the character and the audience.

\section{Yoruba Language}

The structure of the Yoruba language is dual. The indigenous unadulterated Yoruba language is tonal and comprises distinct ethnic varieties. The "akomolede" is the learning type for language literacy and appreciation. The Yoruba indigenous dialect function as a dialectical identity of different ethnic compositions. Examples are Ekiti, Egba, Oyo, Ondo, Ikale, Osun, Igbonna dialects. There are also Yoruba speaking groups in the Diaspora, with their tonal differences as a mark of their own cultural identity. According to Lewis "Yoruba is a tone language spoken in West Africa, by approximately 20 million speakers. It is the native tongue of the Yoruba people. Yoruba is spoken among other languages, in Nigeria, Benin Republic and Togo and in communities in other parts of Africa, Europe, North America and Latin America". Despite the comprehensive numerical strength of Yoruba speakers, the Yoruba cultured moviemakers are saddled with the responsibility to choose their right cast in terms of linguistic competence in the expression of Yoruba language in a native pattern, because, language is one of the pillars of cultural preservatives used to preserve cultural identity and promote Yoruba language literacy. As a strong pillar to project the Yoruba culture, Adeoti's treatise on the Yoruba language is apt:

Yoruba is simple, but it is also characterised by a considerable measure of complexity, with subtext and allusions. Either way, the language captures reality with a musical and imagistic appeal. It is dynamic, quickly adjusting to new situations and circumstances. It is not ashamed to borrow from other languages to enrich its semantic possibilities and captures the daily experience of the world. The video film is, therefore, a contemporary laboratory through which the Yoruba language is experimented. In another metaphor, it is an exhibition canvas where the rich texture of the language, in its mundane and esoteric contemplation, is displayed. The poetic language flows with the verbose and outright prosaic. Proverbs commingle with street slangs, clichés and hackneyed expressions. Puzzling spectacles of incantations sometimes combine with elegiac lamentations or invocations of the denizens of the ethereal world-deities ancestors and spirits [14].

Adeoti's submission above illustrates that the Yoruba language is a composite of elements which occurs out of constant usage of the Yoruba vocabulary. The language expression is an experience lived by both the user, and the hearer to communicate ideas and meanings. Unless an individual is pathologically polyglottic, which is not common, the polyglot experience may not be artistically and commercially viable due to the linguistic impediment of the mother tongue or the first language. A work of art, like dramatic expressions, can only be aesthetically successful before it can be professionally and commercially viable at the box office.

Some prominent Yoruba Nollywod actors who are also polyglots are as follows:

- Ricardo Agbor,

- Mercy Aigbe,

- Fathia Balogun Williams, 
- Kelvin Ikeduba

- Clarion Chukwura,

- Mercy Ebosele,

- Rose Odika,

- Rachael Oniga and

- Regina Chukwu

Acting is a highly skilled profession with a deceptively facile appearance. Ironically, the ultimate test of good acting is the capacity to make it look all so natural and so comfortable, belying the horrendous amount of physical, intellectual and psychological energies that must have gone into the preparation of the role. Acting is undoubtedly far from being the spontaneous, arbitrary art that it may sometimes appear to be. Every speech, movement or gesture is preconceived and carefully ordered to fit into the larger scheme of things; hence, language and its elements are the vehicle to convey believability in role play. Talent is good, technique is necessary; technique must refine and reinforce raw talent for maximum expressiveness. For the versatile multilingual actor, it is a credit on the market value. It is a remarkable feat for the actor and a necessity in a clime where the multiplicity of skill and versatility in acting bring about more jobs. They are bound to be in demand more than strictly monolingual actors who find it challenging to shift border. At the same time, while a passive competence in being multilingual may not attract a professional producer, operational competence of a monolingual will not be able to increase his market value.

A strictly Yoruba speaking actor may not be cast in an English speaking movie. Likewise, a strictly English-speaking Nigerian actor may not be cast in a strictly indigenous movie.

The likes of Akin Lewis, Funso Adeolu, Niyi Johnson, Damola Olatunji, Jaye Kuti, Toyin Aimakhu and Jumoke Odetola are examples of passive polyglots in the Nollywood Yoruba movies. The likes of Toyin Afolayan (Lola Idije), Fausat Balogun (Madam Saje) and Tubosun Odunsi (PaadiMikailup) may not be able to cross the borderline to English or any other language apart from Yoruba. On the other hand, Idowu Phillips (Mama Rainbow) and Lanre Adesina Hassan (Iya Awero) are passively competent polyglots, they speak English and Yoruba, conversationally.

\section{Methodology}

This paper is premised on qualitative research of content analysis, and content analysed visual materials in order to ascertain the linguistic strength of non-native actors in native films. These films include Asa, by Fathia Balogun, Kolokolo by Yinka Laoye and Ifa Iwa, by Abdurasheed Titilope.

\section{Analysis and Discussion of Findings}

In all, three Nigerian films in the Yoruba language were evaluated in their form, mode, content and cultural aesthetics. Thus, the paper appraises three Nollywood Yoruba films, while attention is given to selected major characters in the following Yoruba films.

Table 1. List of Selected Yoruba films Featuring Non-Native Actors in relation to their Linguistic disability

\begin{tabular}{|c|c|c|c|}
\hline S/N & $\begin{array}{c}\text { Film Title } \\
(\mathrm{s})\end{array}$ & $\begin{array}{c}\text { Producer and } \\
\text { Director }\end{array}$ & $\begin{array}{c}\text { Featured } \\
\text { Non-Native Actors } \\
\text { Case Studies }\end{array}$ \\
\hline 1 & Asa & Faithia Balogun & Faithia Balogun \\
\hline 2 & Kolokolo & $\begin{array}{c}\text { Yinka } \\
\text { Laoye/Muideen } \\
\text { Ayinde }\end{array}$ & Toyin Aimakhu \\
\hline 3 & Ifa Iwa & Abdulateef Titilope & Ricardo Agbor \\
\hline
\end{tabular}

These actors, as mentioned above, were chosen for two reasons; one is the fact that they are not of Yoruba descent. The second reason is that they participate in Yoruba films, both indigenous and films with modern settings.

\section{Case Study One -Toyin Aimakhu (T.A.) in the film, Kolokolo: (2018)}

Kolokolo is an epic movie, starring Toyin Aimakhu as one of the major female cast. Kolokolo is also the name of the principal character in the film played by Murphy Afolabi. The character Kolokolo sets out on a vengeful mission, for a crime the governing council of his village committed. He was denied justice over the death of his father killed during a retain raid. He becomes a terror living in exile, having acquired spiritual powers from so many gods of the land. The last of the powers he acquired is from Feyira whom he later marries. Toyin Aimakhu plays Feyira, the spirit daughter of Iroko, who rescues and empowers Kolokolo against his kinsmen. The last straw, which broke the Camel's back, is his reneging on his promise to make Feyira, the only woman in his life. The Iroko spirits of Feyira, turn against him, strip him of all powers and make him powerless.

The video film is star-studded and parades popular native veteran Yoruba actors who are well known for their prowess in Yoruba native renditions. Examples are Murphy Afolabi (Kolokolo), Kola Oyewo (King of Ajeromi), Ronke Ojo (Iyalode), Ogunlakaaye (Alowolodu), Damola Olatunji (Adigun) and Samson Eluwole (Oloye). The flow of the acting is strong, and concentration is high, native language rendition is excellent among the veterans, who are not just conversant but have an excellent mastering Yoruba native expression. Apart from Kola Oyewo and Damola Olatunji who are elites and also bilingual, others are Yoruba native speakers without the impediment of other Yoruba dialects. 
In this film, Toyin Aimakhu displays a conversational skill in Yoruba language expression, but a conversational Yoruba dialect that does not align with the linguistic concept of the film. Here are some examples that analyse the influence of mother tongue of Toyin Aimakhu in speaking Yoruba indigenous language:

(At the bush encounter in a conversation with Kolokolo):

Feyira:

"She eyin leyin onii dekun ibaje ni, em ina o nigba fun yin."

"You do not want to desist from evil? I

Translation: too will not allow it."

Correct "se e lee nii d'ekun ibaje, emi na o phrase: nigba fun in."

Feyira: "O daana, kini o moti o njeeewo?"

Translation: "What do you know about taboo?"

Correct

phrase:

"o daana, kin loo mo tin j'eewo."

(Kolokolo seeking help from Feyira)

"Nigbatimori pe ija eto lo nja, kii se ija

Feyira: ebi, tinba lore timo le she fun o tin mio se bi igbati mobo ore Olodumarem'orani."

"When I discover you are fighting for Translation: what is right and refuse to help you, I am not showing gratitude to the Almighty."

"Ngba n moriipeijaeto loo nja, kii se

Correct ijaebi, bin ba lore timo le se fun o tin o

phrase: si see, biigba $\mathrm{n}$ mo boo ore Olodumarem'orani."

(At the entrance of the abode of other bush spirits, Feyira seeking help for Kolokolo)

Feyira:

"Emi Feyira, omobibioluirokoti o nfi gbogbo ara she omo araye lore."

"I Feyira, the child of the iroko spirit,

Translation:

a helper of human beings."

Correct "Emi Feyira, omobibioluuroko tin fi phrase: $\quad$ gbogboaras' omoarayel'oore."

(Feyira awakens Kolokolo spirit)

Olupemope.Motijaweolusulereloni.o di dandanko je mi, Nitori wipe kini, bi a bapeoku $\mathrm{n}$ popoalaayenindahun.

Feyira: kolokolooo. Iwo, mogbe o leyin tan, o wafe fi gemi je. Mo ni o moshee o si se, enidan 'ru re woo omi. oko lo gbeelo. Emi shetan lati lo, amo bi mo tin loyi, mo lo tiletile.

"I empowered you, you turned against Translation: me. I told you not to attempt it, you dared me, you will see the consequence, I am leaving you with everything."
Correct
"Bi a ba 'oku n popo, alaayenindahun.
phrase:
Mo niomo see o si see. Emi setanati lo...."

\section{Error analysis}

The pronunciation error has led to additional sounds and spelling errors, which also affects the beauty of how Yoruba words are pronounced, and this is not a way of protecting the Yoruba heritage. The rendition of these lines is modern, as evident in the heat of an argument, where the concentration of characterisation is intense, and the flow of thought towards nativity impeded. Being conversational in the Yoruba language did not work for this cast, because although the first language of this cast is Yoruba, the actor is obviously not an in-depth speaker of Yoruba as her first language.

Like most elitist Yoruba Nollywood actors, Toyin's Yoruba indigenous dialect is defective. To the uncritical audience, the deficiency in her renditions will go unnoticed, or better still, misleading in actually communicating the intended meanings of the lines. If analysed side by side with Tola Oladokun, Victoria Ajibola, Ejide, Ronke Ojo (Ronke Osodi Oke), Abeni Agbon and others who are real native Yoruba actors and who hardly participate in modern Yoruba movies, the language defect is certainly apparent especially to the critical audience. So if an audience who knows nothing about how words are important and coined in Yoruba land, this act of Toyin Aimakhu in adding to lexical and phonological structure of Yoruba language has successfully misinformed such an audience, so you see such an audience pronouncing "Tinba" for "bin ba", looking at this from the perspective of Albert Badura's social learning theory (SLT) this act of misinformation of Toyin Aimakhu has a destructive impact over such an audience because of her linguistic defect.

\section{Case Study Two - (F.B.) Fathia Balogun in Asa: (2017)}

Asa was written and produced by Fathia Balogun. Asa is a cultured film by Fathia Balogun. While the film's thematic preoccupation is embedded in its title, the essence of this tragic movie is the desecration of culture and traditions of a Yoruba ethnic community called Onala. Lead actors include Adebayo Salami who is the king, Peju Ogunmola plays the queen, Alagba Faleti is the storyteller, Bukky Wright is the wife of the Prince, Iyiade, while the Prince is played by Muyiwa Ademola, the hero of this traditional drama.

\section{Characterisation and Linguistic Impediment}

Yoruba actors in this film display their dexterity in 
diction as required by the film, Asa. The Olokun priestesses, played by Rachel Oniga and Henrietta Kosoko two veteran actors who are also accurate and fluent in their native Urhobo first language. The character of Ewaade, as played by Fathia Balogun, does not pass without some linguistic defect. Her diction of Yoruba cultured tonality is contrasted in the delivery of her speech and intercepts the creative mood of the actor. She is viewed as floating at the exploration and the complexity in the cultural transposition her character should possess.

Examples of Ewaade's Monologue

Prince: "Iyunn mi."

Translation: "My Iyun."

Iyunade: "O ga o, agodo re wa she bi enipeoun o baori re mo." Translation:

(Iyun Ade monologue) The "o" should have a diacritic underneath it. The 'she' should be 'se'.

Prince: "Eyi mu ti ojowu dani."

Translation: "Are you jealous".

"Firifiri ni oju ati imu wanrira won, ee

Iyunade: tie rantii wa mo, baa ba ranse si yin nko?"

"We do not see each other often

Translation: anymore, what if I did not request to see you?"

Prince: "Bajin o jin $\mathrm{n} g$ o ni wale, Ipo Oba o mo rorun."

Translation: "I am busy".

Iyunade: "Odaa naa nko ri nkan alejo mi o."

Translation: "I missed my menstrual period."

(Iyunade with Queen Ojuolape)

Queen:

"Ngbo kilo sele laarin iwo ati Iyiade?"

"what happened between you and the Prince?"

Iyunade:

Translation:

"Nkankan o shele, mo kan so pe mofe'raku ni."

"nothing happened, I told him I am pregnant."

Queen:

Translation:

“Iwo fe'raku. Nje o mo ewu t'owa nbe, soo mo pe o tini afesona?"

"You say you are pregnant; do you know the danger inherent; do you not know that he has a fiancée?"

"Mo mope won ti ni afesona, mi o Iyunade: $\quad$ so pe ki won fe mi, mokan so te mi ni."

Translation:

\section{Queen:}

Translation:

Iyunade:

Translation:

Correct

phrase:

\section{Error analysis}

Nativity is underplayed in the above rendition, apart from her non-dialectical way of rendering the lines from the beginning of this movie, Fathia Balogun's character is also defective in the linguistic execution of the character Iyunade. The impediment here is the non-dialectical Yoruba, which is known as "Akomolede" Yoruba. That is the tone dialect for the Yoruba literacy appreciation, not the colloquial dialect synonymous with the nativity. As a model it is expected that her character should elevate the ethical value of Yoruba culture as it is noted by Bandura's SLT even looking at the central theme of the play is "ASA" meaning; culture. This fact alone should elevate the sense of interpretation and characterisation of her cultural values as a character that is reflecting a society. This misrepresentation is capable of having longer-term linguistic defect over the audience.

Other veteran Yoruba actors in the film and who are versed in the colloquial Yoruba diction include Tunde Bamgbode (Fokoko), Yinka Quadri, Bose Odogboro (Iya Oyo), Muka Ray as Oyinlola, Oyeniyi Agoro as Awoteju, Ayobami Olabanji as Lukosi, Adetunji Odusanya as Awodeyi and a host of others. Majority of other members of the cast, especially the young actors, are conversational in Yoruba indigenous diction in which the veteran actors mentioned above are skilled. It is evident from the rendition that they struggle to canvass and code-switch between the traditional and the conversational Yoruba diction.

\section{Case Study Three - (R.A.) Ricardo Agbor in Ifa Iwa: (2013)}

Ifa Iwa as the name connotes is the Ifa corpus on human character. Iwa in the Yoruba language connotes righteousness and good moral behaviour. The dramatic narrative is on "character" as Iwa, a necessary virtue in the journey of life. It is a classic movie portraying the lives 
and character of Yoruba gods, and examples are; Orunmila, the chief oracle of Ifa, played by Ricardo Agbor, Sango (Muyiwa Ademola), (Esu Ebita and Esu Laalu) Ibrahim Chattah, Iwa is played by Bidemi Kosoko, Oyeniyi Fagbenga Agoro played the assistant Ifa priest.

\section{Characterisation and Linguistic Impediment}

According to research, Orunmila is the progenitor of the Yoruba race. His character in the physical terrestrial form is that of a wise sage, powerful, knowledgeable, protective, but not unsusceptible to anger, and he was with God at the beginning of creation, he came to the world as a priest of God in the physical form or through his disciples. His manner is tied to the concept of Omoluwabi; meaning, a persona based on good character, and high regard for honour and integrity."

Orunmila's character, as performed by the actor, Ricardo, is not without defects. It is not understandable why the director cast Ricardo, an Efik man, though living in Lagos, as Orunmila, except for his face as an already made star capable of racking in a considerable profit margin. The colloquial rendition of Yoruba language of other lead cast is apparent in their expression as there present flawlessly with understandable cultural diction. As Orunmila, who is a custodian of the knowledge of Ifa, the leading actor is deficient in the native linguistic interpretation a character of his status should possess. To remedy his poor linguistic expression, the director had to interlude with an assistant in the person of Fagbenga Agoro, who renders most of the Ifa corpus and themes with ease. Ricardo's diction as Orunmila may have been acceptable, if the movie was not situated in the prehistoric period, with the expected language was not only indigenised but also colloquial. To a critical mind, the Orunmila portrayed in this movie, Ifa Iwa, is a composite of modern Yoruba language effused with Lagos dialect and nuances in diction. Ricardo's deliberate calmness in the rendition of his lines is an attempt to cover up for this defect. Some of his lines are:

Orunmila: “Olorekinku, olorekinrun".

Correct phrase: "oloorekiiku, oloorekii run".

(Orunmila with wife -Iwa)

Iwa: "Ata re abijosi."

Orunmila: "Ewonin da nbe."

Translated: "Which one is better."

Correct phrase: "Ewo lo da nbe."

Orunmila: "Bin bashetan, ma wa je."

Correct phrase: "Bin ba se tan ng o jeun."

(Orunmila with wife, Osunlaya) Orunmila: "Osunlaya ewo wa l'ogun

"Osunlaya, what's happening to him,

Translation: why did you order him to hold hot pebble?"

\section{Osunlaya: \\ "Ko lee ki ese ifani baba." \\ Orunmila: "Se oun to se noo nu?" \\ Translation: "Is that all?" \\ (to the chiefs): E gbenu yin soun, \\ Orunmila: irukan $\mathrm{n}$ kaun tin r'ugbakaun ,tiyin nan be lara yin" \\ Translation: "You are not better than him, so you too must be stupid to blame him." \\ "E wagbo, seriagba o wakanekomimo, Orunmila: gbogboologbon aye koniagba aye." \\ "Let me tell you, knowledge has nothing to do with old age, wisdom does not come with age, besides the little knowledge he has is because he is under my tutelage and also for his dedication.}

His attempt to be colloquial only reveals his deficiency and made him mechanical, which reduces the aesthetic quality of good diction, which results in unbelievable and robotic characterisation. The character of Orunmila in history never spoke in Lagos dialect, especially of the modern type. The dexterity and ease of his assistant (Fagbenro) provide a ground for comparison, in terms of character interpretation of similar roles played by both. Theatre and Drama is almost the only remaining tool that preserves culture and traditions, which suppose to be at the peak concerns of every filmmaker, the question of culture representation and preservation should prevail over every thought because this is the whole essence of arts. Considering the Bandura's SLT, Ricardo Agbor should not be a perfect character for Orunmila, because of denigrating ethical value in the society. Orunmila is an important god in Yoruba society, and Yoruba people are mostly careful in misrepresenting what he represents in their culture. This study observes that despite this significant flaw of casting and interpretation, the movie still retains its pedagogic essence of Iwa, good character, as an impetus for peaceful cohabitation, a virtue that surpasses religious or philosophical idiosyncrasy.

\section{Discussion of Findings}

Art is sustenance of human value, any act of culturicide is an attempt of colonisation and direct insult to every race of a society. Language, which is an aspect of culture, is an identity and honour of a society, and if anything should be jealously guided, it should be language and culture. This should serve as an exact point of concern for producers and stakeholders to produce films of good cultural standard, for preservation of culture, by choosing the right cast for the Yoruba indigenous movies and also be conscious of the theme in Bandura's Social Learning Theory. Further analysis of the linguistic impediments of polyglot actors in the selected cultured films, revealed that language is an aspect of culture and identity. That even 
though some lead actors who are non-Yoruba natives speak the language fluently, they are unable to express the natural flow of thoughts that come with the mastery of the language in terms of diction, pronunciation, and body expression.

From the outcomes of the film analysis, the study denotes that acting out a story is culture-bound. Whereas, an actor should be a person who has no identity or a culture except the one given by a director or a story. The situation of a story bound actors who are mercenary storytellers, to be striped of any garb of their nativity except that which the story demands. The actor should not wear his or her native ideological sensibilities like a badge, since he is someone who does not exist until a story demands; meaning a culture will be represented, because every story must be set in a particular locale. An actor must acculturate with his role, character and every linguistic requirement of the story in order to be believable. Acculturation, therefore, is not possible without proper training, practice, performance, all of which help his acquisition of skill and technique. The findings of this study has led to the realisation of character's intention to construct an identity of a Yoruba native which is limited through the impediment of tonal inflexion of another nativity, in vowels and consonants expressive quality. Just as identity does not manifest in a single analytic level, which is language alone, cultural identity should also be analysed through diction, and gestures, of the totality of the actor's body.

Language and character identity within a video drama is a process in the transitory and interactive engagement of rehearsals and character assimilation which the film industry underscores, instead it is "shoot on cue," there is simply no rehearsal for the actor before the shoot as it is construed that the actor is a professional. Consequently, the polyglot actor's nuances and diction do not conform to the social and periodic category assigned.

The study also observes that the majority of young Yoruba actors in the Nollywood setting underplay nativity in a native setting. If plays of indigenised nativity abound side by side with the contemporary, perhaps it could have served as an opportunity for this native and non-native cast to try their skill, but unfortunately, the production of historical and cultural plays are becoming fewer by the day. Cinemas too also reject 'total culture' films as part of their viewing product, if it must be shown in cinema halls, then there must be cultural or period diffusion, half cultured, half modern.

Again, one of the fundamental problems is the acceptance of foreign culture as a superior and dominant language of expression in Nigeria. Most people believe that being able to speak in a foreign language and accent is a sign of civilisation. Stakeholders, including the marketers, agree that the right cast should be chosen, regardless of the fame status of the cast. Cinema is a culture; therefore, foreign culture and language deficiency should not be used for the extinction of indigenous culture because, if encouraged, it can lead to a loss of moral values and identity.

It is incontrovertible that no society exists exclusively without borrowing from other cultures; lack of effective cultural gatekeeping will, however, deprive such society of its cultural essence, leading to cultural extinction especially at this age of fast-paced "villagisation". Hence for the Nigerian video film industry to maintain its cultural identity and evolve an indigenous film language, this study has come up with an urgent need for practitioners to reject Hollywood formula and source for local images and idioms. Thus Nigerian filmmakers need to strip the film of its western cloak and adorn it with African garb through the process of indigenisation.

The problem of linguistic impediment is common among the young and trendy actors. The few older veterans actors are being side-lined for lack of glamour and market viability, which is dictated by marketers, thereby, forcing them into extinction or a life of poverty since acting is all they know how to do well. Examples of these veterans are Alapini, Toyosi Arigbabuwo, Olofa'na, Yetunde Isho Pepper, Baba Wande, Kubura Oyin Adejobi, Aderupoko, Fokoko, Eda Onile Ola, Gbolagade Akinpelu, Sokoto. The younger actors who are the saving grace of culture and Yoruba language includes Taofeek Adewale (Digboluja), Ibrahim Chattah, Adewale Alebiosu, Dolapo Ejide, Ronke Oshodi Oke, Murphy Afolabi, Afonja Olaniyi (Sanyeri), Bose Odogboro, and many more.

The connotative submission of this paper is that, polyglot actors in Nollywood Yoruba film industry are not versatile enough due to lack of education and training and the preference for a wider profit margin over qualitative innovation. Most of these actors, especially the Yoruba natives and non-natives with passion for Yoruba cultured plays can be better if time is given to research, practice and production as evident in Ricardo Agbor's role as Orunmila where he floats in between indigenised diction in the wake of modernity.

Furthermore, findings from this study observe that if the industry could enjoy government intervention in the area of investment and funding, some of these problems may be alleviated. With adequate funding, directors may realise their ambition of a standardised and professional movie. Therefore, the relevance of Albert Bandura Social learning theory as examined in this study buttress the postulations of the theory that language impediment can have a long-term influence on the audience, and the danger of such impediment can have adverse effects on the Yoruba language, in terms of learning, culture and understanding.

\section{Conclusions}

This paper considers the problem of multilingual actors 
in the Yoruba film industry to the fact that while some scholars have written extensively on acting by Yoruba native actors, that of non-Yoruba native actors in Yoruba cultured movies have never been considered. The defect in language and characterisation is evident in these films because of their inability to acculturate between two different ethnic languages and culture. Hence the study justified the need for theatre education, versatility, research and training on the part of the actors and standardised creative work of art on the part of producers, who engage in movie making for profit and fame without the right cast. The study concludes as follows:

- One of the essential elements of believable acting is language, which aids the viewers' understanding of the film

- The current trend in the Nollywood Yoruba is the fact that elite actors are multilingual; they speak English, Yoruba and their indigenous language.

- Linguistic impediment is common among the trendy Yoruba actors, and the majority of them are comfortable with stylised modern Yoruba diction; hence they underplay nativity in a native setting. However, underplay of nativity sends wrong interpretative signals; the result is that the aesthetic content of the film is nullified.

- Most non-native polyglot actor's conversational Yoruba dialect affects native characterisation and linguistic interpretation.

- Producers and marketers dictate the choice of cast for the director; they prefer a known face to sell their movies even when such a cast is inappropriate.

- Communication between the actor and the viewing audience is paramount to film culture and appreciation.

\section{Recommendations}

The study recommends as follows:

1. Producers should endeavour to shift from quantity syndrome in terms of profit margin to qualitative products for consumers.

2. Producers and directors must access information and be engaged in innovative research or fact-finding missions in order to disseminate accurate information through their films.

3. Actors must be trained in film art, including speech.

\section{REFERENCES}

[1] Okpadah, S. (2019) "Transnationalism \& Neo-Nollywood: The Nigerian Cinema of the Global Diaspora". In Advanced Communication Research\& Media Studies in Africa. (ed) Balofin. New York: Franklin International Publishers.
[2] Ayakoroma, B. (2014). Trends in Nollywood: A Study of Selected Genres. Ibadan: Kraft Books Limited.

[3] Emmanuel, A. A. (2015). "The Sociolinguistic of a Nollywood Movie". In: Journal of Global Analysis. Vol. 1.no 2 p. 111-138

[4] Ishola, A. (2014) "The Cultural Void Deepens and The Moral Crises Worsens". In the Dimensions of the New Nigerian Theatre: Critical Essays in The Honour of Kola Oyewo. United Kingdom: Alpha Crowns Publisher. p. 45-55

[5] Zentella, Ana. (2004) Bilingualism and Identity: Spanish at the Crossroads with Languages. (eds) Mercedes Nuno Murcia and Jason Rothman et al. Amsterdam: John Benjamin Publishing Co.

[6] Weinrich, U.1979. Language in Contact: Findings and Problems. The Hague: Mouton Publishers.

[7] Bandura, A. (1977). Social Learning theory. New Jersey: Englewood Cliffs, Prentice-Hall Publishers.

[8] Adeleke, D. (1995) Audience Reception of Yoruba Films: Ibadan as a Case Study: PhD Thesis. Linguistics and African Studies, Arts, University of Ibadan.

[9] Driscoll, Marcy. Psychology of Learning For Instruction. N.p: Allyn \&Bacon. 1994. Print.

[10] Weinstein, Claire \& Meyer, Richard. The Teaching of Learning Strategies: Hand book on Research and Teaching. New York: Macmillan. 1986. 315 “327. Print.

[11] Shuell, T. "Cognitive Conception of Learning." Review of Educational Research .56 (4) 1986. 412. Print.

[12] Munroe M. \& Jeffery P. “A Critical Review of the theory and application of Social Learning in participatory natural resource management processes". Journal of Environmental Planning and Management, 2008, 51(3) 325 “344. Print.

[13] Grumperz, J. "Language and Social Identity". Sociology. Cambridge: Cambridge University Press. 13, vol. 4, 454-455

[14] Adeoti, G. (2014). Nigeria Video Films in Yoruba. Lagos: CBAAC Occasional Monograph, No 30.

[15] contentanalysis.http//en.m.wikipedia

[16] www.thefreedictionary.com.>.polyglot

[17] Schechner.www.bric,ac.uk.Parip introduction.htm

[18] Marlin Dwinastiti.Language interference. Voila! CestAlin!

[19] http;/wwwtheactorstore.com.actingtheorypeople

[20] htm study.com/academy/...cultural norms-definitions-value s-quiz.html.

[21] https://en.m.wikipedia.org>stanislavsky

[22] Adatan, K. 2013 on Prezi.http//prezi.com/Language as a Key Aspect of Culture

[23] www.springer.com $>$ content $\square>$ document. List of polyglots-W ikipedia

[24] Ifa Iwa, (2013) Produced by Abdulateef Titilope. Directed by Muyiwa Ademola and Adebayo Tijani 
[25] Asa, (2017) Produced by Fathia Balogun Williams. Directed by Olanrewaju Abiodun
[26] Kolokolo, (2018) Produced by Yinka Laoye and directed by Muideen Ayinde. 